\title{
Viral symptoms in children and SARS-COV-2: information for pediatric dentists for the control of transmission
}

\author{
Thaysa Gomes Ferreira Tenório \\ dos SANTOS(a) iD \\ Débora Heloísa Silva de BRITO(a) iD \\ Natália Maria Velozo dos \\ SANTOS(a) iD \\ Mabel Cristina PAIVA(a) iD \\ Maria Carlla Aroucha LYRA(a) iD \\ Mônica Vilela HEIMER(a) \\ Arnaldo de França CALDAS \\ JÚNIOR $^{(\mathbf{b})}$ iD \\ Aronita ROSENBLATT ${ }^{(a)}$ \\ (a) Universidade de Pernambuco - UPE, \\ School of Dentistry, Department of Pediatric \\ Dentistry, Recife, PE, Brazil. \\ (b) Universidade Federal de Pernambuco - UFPE, \\ School of Dentistry, Department of Patients \\ with Special Needs, Recife, PE, Brazil.
}

Declaration of Interests: The authors certify that they have no commercial or associative interest that represents a conflict of interest in connection with the manuscript.

Corresponding Author:

Thaysa Gomes Ferreira Tenório dos Santos

E-mail: thaysa13ip@gmail.com

htrps://doi.org/10.1590/1807-3107bor-2022.vol36.0029

Submitted: March 20, 2021

Accepted for publication: October 11, 2021

Last revision: November 22, 2021
Abstract: The new coronavi rus, which has spread worldwide, has spiraled out of control in Brazil. The number of infected children has increased, and more Infants Special Care Units are needed to prevent deaths. This study aims to report the most common signs and symptoms in children infected by seasonal respiratory viruses and those infected by COVID-19. This knowledge is essential to educate pediatric dentists, who may contribute to identifying the difference in symptoms and notify the cases, thus preventing the spread of COVID-19. This study was carried out in a Family Health Center of Ipojuca, state of Pernambuco, Brazil, and included 54 children seen for dental emergency care. The parents provided information about the signs and symptoms of their children's health conditions during the lockdown from March to July 2020. All children had a serological test to detect any exposure to the virus. Kolmogorov-Smirnov and Mann-Whitney tests were used to assess the distribution of the data and compare the quantitative variables between the groups. Among the study participants, $16.7 \%$ tested positive for COVID-19. The most prevalent symptoms were headache (38.9\%), sneezing (35.2\%), and fever (20.4\%); six out of nine children with a positive test had symptoms after infection of an adult in the family. Children infected with COVID-19 showed similar clinical signs to those with negative results. Pediatric dentists should acquire knowledge to report on sick children and prevent the spread of the disease.

Keywords: Coronavirus I nfections; Child; Signs and Symptoms.

\section{Introduction}

At the end of 2019, viral pneumonia was first reported in Wuhan, China, and identified as a new beta coronavirus, containing RNA, that infects human cells similarly to the SARS coronavirus and is powerful enough to damage vital organs, such as kidneys, liver, lungs, and heart. ${ }^{1-3}$ The World Health Organization (WHO) named this new disease coronavirus disease 2019 (COVID-19). ${ }^{2}$ Its first symptoms are fever, fatigue, dry cough, and shortness of breath. Other symptoms may appear later, such as sore throat, sneezing, anosmia (decreased olfactory function), and dyspepsia (discomfort in the upper abdomen), and finally, fatal systemic symptoms, including malaise and respiratory failure. ${ }^{4}$ 
Although the world's population at large is susceptible to SARS-CoV-2, many studies have shown fewer cases and less severity in children than in adults. ${ }^{5,6}$ However, the vulnerability of children has increased, including absence of symptoms or fever, cough, and fatigue episodes as the most frequent symptoms. ${ }^{7}$ This broad spectrum of symptoms associated with infection can occur because of the children's higher immune response. ${ }^{8}$

Some studies have reported on pediatric cases of SARS-CoV-2 infection in adults before children are affected. ${ }^{9}$ The authors support the hypothesis that the potential transmission from children to adults is small, with a history of family exposure without evidence of secondary transmission. Studies have suggested that, given the number of asymptomatic children, coughs are less frequent, with lower spread of viral particles. . $11^{11}$

There is some clinical evidence that children are less susceptible to SARS-CoV-2 infection and less likely to develop more severe conditions. ${ }^{12,13}$ It is assumed that the immune system is more efficient in resisting infection in young children than in adults. Also, children have fewer viral receptors, such as angiotensin-converting enzyme 2 (ACE2) and transmembrane serine protease 2 (TMPRSS2), the main proteins in the receptors for coronavirus 2 in acute respiratory syndrome (SARS-CoV-2). Children may also present less virulence and less severity of the disease. ${ }^{14,15}$

Although most children show milder response to the infection and less severe acute respiratory syndrome, there are reports on children who developed a systemic inflammatory response, similar to Kawasaki disease, in COVID-19. ${ }^{16-18}$ Kawasaki disease is the most common primary vasculitis in childhood. In vasculitis, medium-sized and small arteries are affected; gastrointestinal and cardiovascular conditions may also appear, with skin rash, conjunctivitis, headache, and fever. Besides, there may be oral manifestations, such as cheilitis, cleft lips, and erythema multiforme, ${ }^{16,19,20}$ which need to be recognized by dentists.

The most common laboratory tests for detecting COVID-19 in infected people are RT-PCR and serological tests. Collection of genetic material from nasopharyngeal and oropharyngeal swabs is the gold standard. ${ }^{19}$ The serological test is performed on a blood sample and aims to quantify the level of antibodies produced against the virus; thus, one can diagnose the previous disease or determine if the patient had the virus. When IgM/IgA antibodies are detected, recent exposure is assumed to have occurred. These antibodies may indicate an acute phase of the disease, whereas their presence represents previous exposure. ${ }^{21,22}$

This new virus is more transmissible than other coronaviruses, making early diagnosis extremely important for the treatment and disease control ${ }^{21}$. The current approach to nucleic acid testing for SARS-CoV-2, however, has a slight risk of false-negative results; but serological tests are a powerful approach to achieving the timely diagnosis of COVID-19.21,22 The antibodies detected in serology are anti-SARS-CoV-2, including two sub sets (IgM and IgG antibodies). Studies have indicated SARS-CoV-2 IgM is found in the sera of patients with COVID-19, nine days after disease onset, whereas SARS-CoV-2 IgG is present in patient s' sera two weeks after exposure. ${ }^{23,24} \mathrm{~A}$ ppropriate levels of antiviral antibodies prevent patients from being reinfected by the virus; however, recent reports have indicated inadequate levels of serum antibodies can expose patients to reinfection..$^{25}$

In March 2021, the number of hospitalizations of children with COVID-19 skyrocketed throughout Brazil, indicating a rampant pandemic. ${ }^{26}$. This disease is still surrounded by many uncertainties as to how the infection develops in children; there is a need to understand its clinical course to better control and reduce its transmissibility, allowing for its identification through a targeted anamnesis even before the child sits in the dental chair. It is also necessary for the pediatric dentist to recognize the signs and symptoms of COVID-19 in a child in order to prevent transmission. Thus, the present study aims to assess the most prevalent signs and symptoms in children whose parents reported illnesses during the lockdown period, comparing the results of the serological tests for COVID-19 in Ipojuca, state of Pernambuco, Brazil-PE.

\section{Methodology}

This is a cross-sectional study with a descriptive and analytical approach. The study area covers two 
Family Health Centers in the Nossa Senhora do O district, in Ipojuca. Ipojuca is 50 kilometers far from the state capital of Pernambuco, is part of the Metropolitan Region of Recife, has an estimated population of 97,669 inhabitants and a territorial area of 521,801 square kilometers.

The dental team traveled to Ipojuca once a week to help with dental emergency treatment for children during the first lockdown period. The pediatric dentists from Ipojuca were older and at higher risk of being infected; therefore, $g$ raduate students volunteered for the job. A convenience sample with 54 children aged 6 to 9 years was used. Children excluded from the sample had some health conditions that prevented examination, such as blood dyscrasias and behavioral changes such as attention deficit hyperactivity disorder.

The data were registered in a standardized form filled out by parents. The form contained questions about demographics, children's health status, and signs and symptoms of children's diseases, and whether parents had symptoms of COVID-19 from March to November 2020, the lock down period established by the State Government.

A third-party laboratory hired to perform the serological tests also collected the blood samples to qualify and quantify the antibodies produced against COVID-19.

Given the nurses' expertise in collecting blood from children, the participants reported no complaints or suffering. Testing indicated whether the new coronavirus caused the disease reported by parents. Parents had rapid feedback from the health team about the test results.

The data were expressed as $d$ escriptive and absolute values and percentage frequencies for categorical variables and measures - mean and standard deviation (mean $\pm \mathrm{SD}$ ) and median for the numerical variables were calculated. Fisher's exact test assessed the association between the two categorical variables. The Mann-Whitney test compared the two categories of numerical variables. The Shapiro-Wilk test verified data normality.

The margin of error used for the statistical tests was $5 \%$ - the data were typed into an EXCEL spreadsheet. IMBSPSS version 25 was used for the statistical analyses.
This study was developed in compliance with Resolution 466/2012 CNS and was approved by the Research Ethics C ommittee (process no: 4. 203. 296). Parents signed a free and informed consent form for the participation of the children in the study after being informed about the research purposes, the risks involved, and clinical examinations.

\section{Results}

Because schools are still closed, and Health Centers are still partially open, there are a reduced number of children in this study, as the pandemic hindered their recruitment. For dental emergency purposes, only those children seen at the health centers participated in this study. The sample consisted of children aged $6(31.5 \%)$ and 7 (38.9\%) years. As for family income, $40.7 \%$ of the monthly wages were equivalent to US\$ 200 (35.2\%) - only $24.1 \%$ had a family income higher than 200 US\$. Regarding parental education, the percentage for incomplete elementary education, elementary education, and higher education was $31.5 \%$. Only $3.7 \%$ had higher education, and $1.8 \%$ were not educated (Table 1).

Table 1. Sample characteristics.

\begin{tabular}{lc}
\hline Variables & $\mathrm{n}(\%)$ \\
\hline Age (years) & $17(31.5)$ \\
6 & $21(38.9)$ \\
7 & $9(16.7)$ \\
8 & $7(13.0)$ \\
9 & \\
Sex & $24(44.4)$ \\
Male & $30(55.6)$ \\
Female & \\
Family income & $19(35.2)$ \\
$<200$ dollars & $22(40.7)$ \\
$=200$ dollars & $13(24.1)$ \\
$>200$ dollars & \\
Parental education & $1(1.8)$ \\
None & $17(31.5)$ \\
Incomplete elementary school & $17(31.5)$ \\
Elementary school & $17(31.5)$ \\
High school & $2(3.7)$ \\
Higher education & \\
\hline
\end{tabular}


Children whose parents/guardians reported that children were ill during the lock down period accounted for $31.5 \%$. Headache $(38.9 \%)$, runny nose $(38.9 \%)$, sneezing (35.2\%), cough (29.6\%), sore throat $(24.1 \%)$, and fever $(20.4 \%)$ were the most frequent symptoms.

The immunoglobulin test results indicated that nine $(16.7 \%)$ children had COVID-19, but one case was undetermined. A total of eight (14.8\%) patients were positive for IgG, and one was positive for both IgG and IgM (Table 2).

In this study, we tested the association between the serological test for COVID-19 and the symptoms described by parents. Fever was the most frequent sign ; however, there were no significant associations $(p>0.05)$ between any of the variables with the presence of immunoglobulins ( Table 3).

According to the parents, most children had some symptoms during the lock down period (75.5\%), and there were more symptoms in those with a positive

Table 2. Signs and symptoms of COVID-19 and neutralizing proteins ( $\lg G$ and $\lg M)$.

\begin{tabular}{lc}
\hline Variables & $n(\%)$ \\
Was your child sick? & $17(31.5)$ \\
Yes & $37(68.5)$ \\
No & \\
Did your child have? & $11(20.4)$ \\
Fever & $2(3.7)$ \\
Shortness of breath & $2(3.7)$ \\
Fatigue & $16(29.6)$ \\
Cough & $13(24.1)$ \\
Sore throat & $21(38.9)$ \\
Headache & $4(7.4)$ \\
Body aches and malaise & $8(14.8)$ \\
Diarrhea & $21(38.9)$ \\
Runny nose and stuffy nose & $19(35.2)$ \\
Sneezing & $1(1.8)$ \\
Comorbidity & \\
COVID-19 (immunoglobulin test) & $9(16.7)$ \\
Positive & $44(81.5)$ \\
Negative & $1(1.8)$ \\
Indeterminate & \\
Immunoglobulin test result & $44(81.5)$ \\
Absent & $8(14.8)$ \\
IgG present & $1(1.8)$ \\
IgG and lgM present & $1(1.8)$ \\
IgG absent and IgM indeterminate & \\
\hline
\end{tabular}

test for COVID-19 (55.6\%), as shown in Table 4. In this sample, all children who fell ill presented symptoms, showing a significant association $(p<0,05)$ between the presence of symptoms and the occurrence of disease (Table 5). However, children who were positive for IgG and IgM had more than one symptom. Five of the children who tested positive did not present symptoms, which may be due to the presence of mild symptoms or to memory bias.

Regarding parental education, Table 6 shows the parents of COVID-19-positive children had a higher percentage of secondary / higher education (21.1\%). Among those children with a negative test, their parents had a higher rate of incomplete primary education $(89.9 \%)$, but with no statistical significance $(\mathrm{p}>0.05)$.

Six out of nine children who tested positive for the virus presented with symptoms after an adult family member became sick. Those children whose tests were not conclusive did not have ill parents or siblings during the lockdown period.

\section{Discussion}

Studies have indicated COVID-19 in children is generally less severe ${ }^{27,28}$ than in adults, giving a broad spectrum of signs and symptoms, ranging from no symptoms to severe symptoms. These symptoms, which have been well described in the literature, are often overlooked because of their wide variation and low morbidity. ${ }^{28}$

According to the parents, those children who fell ill during the lock down period had fever, headache, and runny nose as the main signs and symptoms. A more significant association of symptoms was observed in children who tested negative for COVID-19. Corroborating the findings of other studies, the prevalence of these symptoms can also be associated with different clinical signs, such as cough, diarrhea, and sore throat., ${ }^{78}$

As reported by parents/guardians, children who tested negative for COVID-19 presented with clinical manifestations similar to those of children who tested positive, including fever, cough, and sore throat, as described by Blondiaux et al. ${ }^{17}$ The difficulties in diagnosing COVID-19in children are that many symptoms are similar to those of other viral infections, requiring parental awareness in order to prevent transmissibility. ${ }^{29}$ 
Table 3. Most frequent signs and symptoms and serological test for COVID-19

\begin{tabular}{|c|c|c|c|c|c|}
\hline \multirow{2}{*}{ Symptons } & Positive $(\mathrm{n}=9)$ & Negative $(n=44)$ & Total group $(\mathrm{n}=53)$ & \multirow{2}{*}{$\mathrm{p}$-value } & \multirow{2}{*}{ OR $(95 \% \mathrm{Cl})$} \\
\hline & $\mathrm{n}(\%)$ & $\mathrm{n}(\%)$ & $\mathrm{n}(\%)$ & & \\
\hline Child was sick & & & & $0.445^{*}$ & \\
\hline Yes & $4(44.4)$ & $13(29.5)$ & $17(32.1)$ & & $1,9(0,4-8,3)$ \\
\hline No & $5(55.6)$ & $31(70.5)$ & $36(67.9)$ & & 1.00 \\
\hline Child had fever & & & & $0.076^{*}$ & \\
\hline Yes & $4(44.4)$ & $7(15.9)$ & $11(20.8)$ & & $4,2(0,9-19,8)$ \\
\hline No & $5(55.6)$ & $37(84.1)$ & $42(79.2)$ & & 1.00 \\
\hline Child had cough & & & & $1.000^{*}$ & \\
\hline Yes & $3(33.3)$ & $13(29.5)$ & $16(30.2)$ & & $1,2(0,3-5,5)$ \\
\hline No & $6(66.7)$ & $31(70.5)$ & 37 (69.8) & & 1.00 \\
\hline Child had sore throat & & & & $0.672^{*}$ & \\
\hline Yes & $3(33.3)$ & $10(22.7)$ & $13(24.5)$ & & $1,7(0,4-8,0)$ \\
\hline No & $6(66.7)$ & $34(77,3)$ & $40(75.5)$ & & 1.00 \\
\hline Headache & & & & $1.000^{*}$ & \\
\hline Yes & $4(44.4)$ & $17(38.6)$ & $21(39.6)$ & & $1,3(0,3-5,4)$ \\
\hline No & $5(55.6)$ & $27(61.4)$ & $32(60.4)$ & & 1.00 \\
\hline Diarrhea & & & & $0.611^{*}$ & \\
\hline Yes & $2(22.2)$ & $6(13.6)$ & $8(15.1)$ & & $1,8(0,3-10,8)$ \\
\hline No & $7(77.8)$ & $38(86.4)$ & 45 (84.9) & & 1.00 \\
\hline Runny nose and stuffy nose & & & & $0.456^{*}$ & \\
\hline Yes & $5(55.6)$ & $16(36.4)$ & 21 (39.6) & & $2,2(0,5-9,3)$ \\
\hline No & $4(44.4)$ & $28(63.6)$ & $32(60.4)$ & & 1.00 \\
\hline Sneezing & & & & $0.706^{*}$ & \\
\hline Yes & $4(44.4)$ & $15(34.1)$ & 19 (35.8) & & $1,5(0,4-6,6)$ \\
\hline No & $5(55.6)$ & 29 (65.9) & 34 (64.2) & & 1.00 \\
\hline
\end{tabular}

Table 4. Prevalence of symptom s and serological test results for COVID-19.

\begin{tabular}{|c|c|c|c|c|c|}
\hline \multirow{2}{*}{ Variables } & Positive ( $\mathrm{n}=9$ ) & Negative $(n=44)$ & Total group $(\mathrm{n}=53)$ & \multirow{2}{*}{ p-value } & \multirow{2}{*}{ OR $(95 \% \mathrm{Cl})$} \\
\hline & n (\%) & n (\%) & $\mathrm{n}(\%)$ & & \\
\hline Had symptoms & & & & $0.424^{*}$ & \\
\hline Yes & 8 (88.9) & $32(72.7)$ & $40(75.5)$ & & $3,0(0,3-26,6)$ \\
\hline No & $1(11.1)$ & $12(27.3)$ & $13(24.5)$ & & 1.00 \\
\hline Number of symptoms & & & & $0.418^{*}$ & \\
\hline None & $1(11.1)$ & $12(27.3)$ & $13(24.5)$ & & 1.0 \\
\hline $1-2$ & $3(33.3)$ & $18(40.9)$ & $21(39.6)$ & & $2,0(0,18-21,6)$ \\
\hline $3-7$ & $5(55.6)$ & $14(31.8)$ & 19 (35.8) & & $4,3(0,4-41,9)$ \\
\hline Number of symptoms & & & & $0.212^{* *}$ & \\
\hline Mean \pm SD & $2,78 \pm 1,79$ & $2,09 \pm 2,12$ & $2,21 \pm 2,07$ & & \\
\hline Median (P25;P75) & $3,00(1,50 ; 4,00)$ & $1,00(0,00 ; 3,00)$ & $2,00(0,50 ; 3,50)$ & & \\
\hline
\end{tabular}

*Fisher' s exact test; ${ }^{* *}$ Mann-Whitney test.

Since the beginning of the pandemic, there has been evidence that social distancing and hygiene can reduce the transmissibility of the infection.
Individuals with more years of formal education tend to be more exposed to the virus, given that they have better job opportunities. Thus, they need 
Table 5. Presence of symptoms according to the parents regarding the occurrence of disease.

\begin{tabular}{lcccc}
\hline \multirow{2}{*}{ Child fell ill during the pandemic } & Yes & No & Total & p-value \\
\cline { 2 - 4 } & $\mathrm{n}(\%)$ & $\mathrm{n}(\%)$ & $\mathrm{n}(\%)$ & $0.005^{* * *}$ \\
Yes & $17(100.0)$ & $14(100.0)$ & $37(100.0)$ \\
No & $23(62.2)$ & $14(25.9)$ & $54(100.0)$ & \\
Total & $40(74.1)$ & & \\
\hline
\end{tabular}

*Significant association at $5 \%$; ${ }^{* *}$ Fisher' s exact test.

Table 6. Results of serological tests for COVID-19 and parental education

\begin{tabular}{lcccc}
\hline \multirow{2}{*}{ Parental education } & Positive & Negative & Total & p-value \\
\cline { 2 - 4 } & $\mathrm{n}(\%)$ & $\mathrm{n}(\%)$ & $\mathrm{n}(\%)$ & $18(100.0)$ \\
Incomplete elementary education & $2(11.1)$ & $13(89.9)$ & $16(100.0)$ & $0.734^{*}$ \\
Elementary education & $3(18.8)$ & $15(78.9)$ & $19(100.0)$ \\
High school/ higher education & $4(21.1)$ & $44(83.0)$ & $53(100.0)$ \\
Total & $9(17.0)$ & &
\end{tabular}

*Fisher' s exact test.

to keep on working and this tends to reduce social distancing. ${ }^{30}$ However, in the present study, there was no association between the parental education and reports on the presence of infection in children.

The most reliable tests for detecting the coronavirus are reverse-transcription polymerase chain reaction (RT-PCR) and serological tests. Serological tests, used in the present study, cause minor discomfort to pediatric patients and allow identifying active disease cases, previous contact with the virus, and immunity. ${ }^{31}$ In this study, most children with a positive test had IgG antibodies, which indicates previous disease or immunity against the virus, as reported by Totura and Baric. ${ }^{23}$

Even with mild or no symptoms, children can harbor high levels of the virus in their upper respiratory tract, especially at the onset of the infection ${ }^{32}$. In the present study, most children who experienced some symptoms reported by their parents had mild symptoms, with a clinical course similar to that of other viral diseases, making it difficult to control the spread of the disease. According to data from the monitoring system created by researchers from the University of São Paulo to keep track of the progress of the pandemic in Brazil, there is an average growth of $15 \%$ in hospitalizations of children with COVID-19 aged 5 to 9 years, compared with December 2020 to February 2021. ${ }^{26}$

Given the current scenario, pediatric dentists are challenged to provide dental care to children by using strategies that help change the behavior of children and parents/guardians. ${ }^{33}$ Despite the new safety protocols, which can make oral examination more difficult, it is essential to focus on evaluating the signs and symptoms of COVID-19 in children. It is also essential to guide families, so they can be aware of the similarities between the symptoms of COVID-19 and of other common viral diseases in childhood. ${ }^{34}$

Education of pediatric dentists in the pandemic should focus on providing them with knowledge about the signs and symptoms of COVID-19 in children to prevent the spread of the disease in clinical practice. ${ }^{35}$

A strength of the present study is its contribution to gathering more evidence that children are not free from being infected, either presenting with no symptoms or being asymptomatic, as signs and symptoms of the disease are similar to those of other viral infections. More severe conditions have been increasingly reported in Pernambuco and throughout Brazil, as described by the State Department of Health epidemiological bulletin and by the Brazilian Ministry of Health. ${ }^{36,37}$

\section{Conclusion}

In this study, parents reported the most common clinical signs in children who tested positive for COVID-19 were headache, cough, and runny nose, with a clinical course similar to that of children with a negative test. These findings indicate the need for further studies on COVID-19 infection in children, 
as the signs and symptoms are similar to those of other viral infections, even though children may be asymptomatic. It is important to highlight that children are not free from the presence of the virus.

\section{Acknowledgments}

The Foundation for the Support of Science and Technology of the State of Pernambuco (FACEPE) provided financial support for this study.

\section{References}

1. Leung C. Clinical characteristics of COVID-19 in children: are they similar to those of SARS? Pediatr Pulmonol. 2020 Jul;55(7):1592-7. https://doi.org/10.1002/ppul.24855

2. Qiu H, Wu J, Hong L, Luo Y, Song Q, Chen D. Clinical and epidemiological features of 36 children with coronavirus disease 2019 (COVID-19) in Zhejiang, China: an observational cohort study. Lancet Infect Dis. 2020 Jun;20(6):689-96. https://doi.org/10.1016/S1473-3099(20)30198-5

3. Lu R, Zhao X, Li J, Niu P, Yang B, Wu H, et al. Genomic characterisation and epidemiology of 2019 novel coronavirus: implications for virus origins and receptor binding. Lancet. 2020 Feb;395(10224):565-74. https://doi.org/10.1016/S0140-6736(20)30251-8

4. Hemmati F, Saedi S, Hemmati-Dinarvand M, Zarei M, Seghatoleslam A. Mysterious Virus: A Review on Behavior and Treatment Approaches of the Novel Coronavirus, 2019-nCoV. Arch Med Res. 2020 Jul;51(5):375-83. https://doi.org/10.1016/i.arcmed.2020.04.022

5. Wu Z, McGoogan JM. Characteristics of and important lessons from the Coronavirus Disease 2019 (COVID-19) surto na China: resumo de um relatório de 72314 casos do Centro Chinês para Controle e Prevenção de Doenças. JAMA. 2020;323:1239-42. https://doi.org/10.1001/jama.2020.2648

6. Song W, Li J, Zou N, Guan W, Pan J, Xu W. Clinical features of pediatric patients with coronavirus disease (COVID-19). J Clin Virol. 2020 Jun;127:104377. https://doi.org/10.1016/i.jcv.2020.104377

7. Huang Y, Tu M, Wang S, Chen S, Zhou W, Chen D, et al. Clinical characteristics of laboratory confirmed positive cases of SARS-CoV-2 infection in Wuhan, China: a retrospective single center analysis. Travel Med Infect Dis. $2020 \mathrm{Jul}$ - Aug;36:101606. https://doi.org/10.1016/i.tmaid.2020.101606

8. Dagan R, Bhutta ZA, Quadros CA, Garau J, Klugman KP, Khuri-Bulos N, et al. O desafio restante da pneumonia: a principal causa de morte de crianças. Pediatr Infect Dis J. 2011;30:1-2. https://doi.org/10.1097/INF.0b013e3182005389

9. Posfay-Barbe KM, Wagner N, Gauthey M, Moussaoui D, Loevy N, Diana A, et al. COVID-19 in Children and the Dynamics of Infection in Families. Pediatrics. 2020 Aug;146(2):e20201576. https://doi.org/10.1542/peds.2020-1576

10. Lee B, Raszka WV Jr. COVID-19 Transmission and children: the child is not to blame. Pediatrics. 2020 Aug;146(2):e2020004879. https://doi.org/10.1542/peds.2020-004879

11. Zhang ZJ, Yu XJ, Fu T et al. Novel coronavirus infection in newborn babies under 28 days in China. Eur Respir J. 2020;58(5). https://doi.org/10.1183/13993003.00697-2020)

12. Li W, Zhang B, Lu J, Liu S, Chang Z, Cao P et al. The characteristics of household transmission of COVID-19. Clin Infectar Dis. 2020;71(8):1943-6.

13. Saheb Sharif-Askari N, Saheb Sharif-Askari F, Alabed M, Temsah MH, Al Heialy S, Hamid Q, et al. Airways expression of SARS-CoV-2 Receptor, ACE2, and TMPRSS2 is lower in children than adults and increases with smoking and COPD. Mol Ther Methods Clin Dev. 2020 May;18:1-6. https://doi.org/10.1016/i.omtm.2020.05.013

14. Van Bever HP, Chng SY, Goh DY. Childhood severe acute respiratory syndrome, coronavirus infections and asthma. Pediatr Allergy Immunol. 2004 Jun;15(3):206-9. https://doi.org/10.1111/j.1399-3038.2004.00137.x

15. Toubiana J, Poirault C, Corsia A, Bajolle F, Fourgeaud J, Angoulvant F, et al. Kawasaki-like multisystem inflammatory syndrome in children during the covid-19 pandemic in Paris, France: prospective observational study. BMJ. 2020 Jun;369:m2094. https://doi.org/10.1136/bmi.m2094

16. Galván Casas C, Català A, Carretero Hernández G, Rodríguez-Jiménez P, Fernández-Nieto D, Rodríguez-Villa Lario A, et al. Classification of the cutaneous manifestations of COVID-19: a rapid prospective nationwide consensus study in Spain with 375 cases. Br J Dermatol. 2020;138(1):71-77. https://doi.org/10.1111/bjd.19163

17. Bouaziz JD, Duong T, Jachiet M, Velter C, Lestang P, Cassius C et al. Vascular skin symptoms in COVID-19: a French observationall study. J Eur Acad Dermatol Venereol. 2020 Sep ;34(9):e451-e452. doi: 10.1111/idv.16544. Epub 2020 Jul 20.

18. Blondiaux E, Parisot P, Redheuil A, et al. Cardiac MRI of Children with Multisystem Inflammatory Syndrome (MIS-C) associated with COVID-19: case series. Radiology. 2020 Dec;297(3). https://doi.org/10.1148/radiol.2020202288 
Viral symptoms in children and SARS-COV-2: information for pediatric dentists for the control of transmission

19. Chiotos K, Bassiri H, Behrens EM, Blatz AM, Chang J, Diorio C et al. Multisystem Inflammatory Syndrome in Children during the COVID-19 pandemic: a case series. J Pediatric Infect Dis Soc. 2020 Jul 13;9(3):393-398. https://doi.org/10.1093/ipids/piaa069

20. Liu Y, Liu Y, Diao B, Ren F, Wang Y, Huang Q. Diagnostic indexes of a rapid IgG/lgM combined antibody test for SARS-CoV-2 [internet]. medxriv. 2020 Mar. https://doi.org/10.1101/2020.03.26.20044883

21. Zhang $P, G a o Q$, Wang $T, K e Y, M o F$, Jia R et al. Evaluation of recombinant nucleocapsid and spice protein serological diagnosis of novel coronavirus disease 2019 (COVID-19) [internet]. medxriv. 2020 Sep. https://doi.org/10.1101/2020.03.17.20036954

22. Zhang W, Du RH, Li B, Zheng XS, Yang XL, Hu B et al. Molecular and serological investigation of 2019-nCoV infected patients: implication of multiple shedding routes. Emerg Microbes Infect. 2020 Feb;9(1):386-9. https://doi.org/10.1080/22221751.2020.1729071

23. Totura AL, Baric RS. SARS coronavirus pathogenesis: host innate immune responses and viral antagonism of interferon. Curr Opin Virol. 2012;2(3):264-75. https://doi.org/10.1016/i.coviro.2012.04.004

24. Abdolreza E, Elahi R. Immunobiology and immunotherapy of COVID-19: a clinically updated overview. J Cell Physiol. 2021 Apr;236(4):2519-43. https://doi.org/10.002/jcp.30076

25. Leng Z, Zhu R, Hou W, Feng Y, Yang Y, Han Q, et al. Transplantation of ACE2- Mesenchymal Stem Cells Improves the Outcome of Patients with COVID-19 Pneumonia. Aging Dis. 2020 Mar;11(2):216-228 https://doi.org/10.14336/AD.2020.0228

26. Rede Brasil Atual. Internações de crianças com covid-19 disparam em todo o Brasil. Revista Brasil. 2021 Mar 16 [cited 2021 Mar 18]. Avaible from: https://www.redebrasilatual.com.br/saude-e-ciencia/2021/03/internacoes-criancas-covid-19-disparam-brasil/

27. Cai J, Xu J, Lin D, Yang Z, Xu L, Qu Z et al. A case series of children with a new coronavirus infection in 2019: clinical and epidemiological. Clin Infect Dis. 2020;71(6):1547-51. https://doi.com/10.1093/cid/ciaa198

28. Lu X, Zhang L, Du H, et al. SARS-CoV-2 infection in children. N Engl J Med. 2020 Apr;382:1663-1665. https://doi.org/10.1056/NEJMc2005073

29. Cleach LL, Dousset L, Assier H, et al. Most chilblais observed during the COVID-19 outbreak occur in patients who are negative for COVID-19 on polymerase chain reaction and serology testing. Br J Dermatol. 2020 Nov;183(5):866-74. https://doi.org/10.1111/bjd.19377

30. Barros AJ, Victora CG, Menezes AM, Horta BL, Hartwig F, Victora G, et al. Social distancing patterns in nine municipalities of Rio Grande do Sul, Brazil: the Epicovid19/RS study. Rev Saude Publica. 2020;54:75. https://doi.org/10.11606/s1518-8787.2020054002810

31. Cheng MP, Papenburg J, Desjardins M, Kanjilal S, Quach C, Libman M, et al. Diagnostic testing for severe acute respiratory syndrome-related coronavirus-2: a narrative review. Ann Intern Med. 2020 Jun;172(11):726-33. https://doi.org/10.7326/M20-1301

32. Patel R, Babady E, Theel ES, Storch GA, Pinsky BA, St. George K, et al. Report from the American Society for Microbiology COVID-19 international summit, 23 march 2020: value of diagnostic testing for SARS-CoV-2/COVID-19. mBio. 2020 Mar/Apr;11(2):e00722-20. https://doi.org/10.1128/mBio.00722-20

33. Meyer BD, Casamassimo P, Vann WF Jr. An algorithm for managing emergent dental conditions for children. J Clin Pediatr Dent. 2019;43(3):201-6. https://doi.org/10.17796/1053-4625-43.3.10

34. American Academy of Pediatric Dentistry. Re-emergence pediatric dentistry practice checklist: a guide for re-entry into practice for pediatric dentists during the COVID-19 pandemic. 2020 Apr 28 [cited 2021 Jun]. Available from: https://www.aapd.org/globalassets/media/covid-19/aapd-practicechecklist.pdf

35. Amorim LM, Maske TT, Ferreira SH, Santos RB, Feldens CA, Kramer PF. New post-COVID-19 biosafety protocols in dentistry. Pesq Bras Odontopediatria Clin Integr. 2020;20 suppl:e0117. https://doi.org/10.1590/pboci.2020.117

36. Secretaria de Saúde (PE). Boletim Covid-19: comunicação SES-PE. 2021 Mar. 15 [cited 2021 Mar 20]. Available from: https://drive.google.com/file/d/1bHVj1rhFZvz4Fvbrlq35kxu5Y4_hAClz/view

37. Ministério da Saúde (BR). Secretaria de Vigilância em Saúde. Boletim Epidemiológico Especial. Doença pelo Coronavírus COVID-10. Semana Epidemiológica 8. 2021 Feb [cited 2021 Mar 18]. Available from: https://www.gov.br/saude/pt-br/media/pdf/2021/marco/05/boletim_epidemiologico_covid_52_final2.pdf 